\title{
Differences in the Salivary Parameters and Caries Status Between the Underweight, Normal, and Obese Children in Medan Primary Schools
}

\author{
Siti $\mathrm{S}^{1, *}$, Irdayanti $\mathrm{S}^{2}$, Christa $\mathrm{P}^{2}$ \\ ${ }^{1}$ Department of Paediatric Dentistry, Faculty of Dentistry, Universitas Sumatera Utara \\ ${ }^{2}$ Faculty of Dentistry, Universitas Sumatera Utara \\ *Corresponding author.Email : salmiadentist@yahoo.co.id, irdayantisr@gmail.com, patriciachrista@yahoo.com
}

\begin{abstract}
The prevalence of dental caries among primary school children in Medan city is substantially high. The primary objective of this study was to analyze the relationship between the salivary parameters, caries status and nutritional status of the primary school children in Medan city. This cross-sectional study utilized a sample of 75 children aged 6 to 12 years old. The salivary parameters of each child were measured using the GC Saliva-Check Kit and the caries status was subsequently measured according to the tenets of the World Health Organization (WHO). The recorded mean body mass index (BMI) was $12.43 \mathrm{~kg} / \mathrm{m}^{2}$ for the underweight group, $16.33 \mathrm{~kg} / \mathrm{m}^{2}$ for the normal group, and $25.64 \mathrm{~kg} / \mathrm{m}^{2}$ for the obese group. The mean deft value for the underweight group was $2.68 \pm 3.61$, for the normal group was $1.16 \pm 1.59$, and for the obese group was 2.04 \pm 2.92 . The mean DMFT value for the underweight group was $2.44 \pm 2.08$, for the normal group was $1.16 \pm 1.17$, and for the obese group was $2.12 \pm 2.29$. There was a significant difference in saliva volume, flow rate, and $\mathrm{pH}$ between the underweight, normal, and obese children. This study had conclusively proven that BMI has a significant impact on the salivary parameters and caries status in children.
\end{abstract}

Keywords: BMI, Children, Salivary parameters, Caries status

\section{INTRODUCTION}

The nutritional status is a type of health status that resulted from the consonance between nutrient need and consumption. The most susceptible group to nutrition-related problems is school children [1]. Nutritional problem is analogous with malnutrition. Malnutrition refers to the condition in which an individual has an improper daily nutritional intake. This condition may be attributable to either underconsumption or in some cases, over-consumption of food [2]. Underweight and obesity are severe forms of malnutrition; hence these two groups require proper nutritional consultation [3].

Underweight can be categorized as a condition in which the body mass is far below the normal threshold, whereas obesity is an abnormality or a disease that is a repercussion from over-accumulation of fats in the tissue $[4,5]$. According to the recently published 2010 Indonesian Health Report, underweight children are defined as children whose age-related BMI is <-3 SD, whereby normal children have a range between -2 SD to $1 \mathrm{SD}$, and obese children with>2 SD [6].
The nutritional status can affect the saliva secretion in children. Saliva is an exocrine fluid that is continuously secreted into the oral cavity via the salivary glands. Many studies had postulated that the human saliva contains $99 \%$ water and $1 \%$ ions and organic elements. The entire salivary secretion mechanism is tightly controlled by the sympathetic and parasympathetic nervous system. Despite its involuntary command, saliva secretion can be affected by other factors, viz., type of stimulus, size of the salivary gland, gag reflex, smell reflex, unilateral stimulation, and diet [7].

An underweight child may have a dysfunctional salivary gland prompted by hypertrophy of the gland which subsequently reduces the salivary flow rate $[2$, 8]. The diminished salivary flow rate could also be a common finding in obese children. This is triggered by the accumulation of fat tissue (adipose) in the salivary glands [9]. Saliva has paramount importance in the food digestion process, modulating the osmotic balance, a self-cleaning agent, and regulator of microbial activity within the oral cavity. Therefore, the receded salivary flow rate in underweight and obese children would 
undoubtedly aggravate the risk of dental caries. This is possible as bacterial adhesion on the dental surface can occur easily without impediment due to diminished self-cleaning activity $[10,11]$.

\section{MATERIAL AND METHODS}

This study was conducted on 25 underweight children, 25 normal children, and 25 obese children aged 6 to 12 years old in Medan. The inclusion criteria were children that are included in the BMI-for-age underweight, normal, and obese, not wearing orthodontic appliances and not having any systemic disease.

Category and z-score of the nutrition status of the children are adjusted along with the Menkes RI 2010. BMI-for-age was obtained by measuring the weight (kg) divided by height $\left(\mathrm{m}^{2}\right)$ and adjusted with the predetermined $\mathrm{z}$-score. BMI-for-age of underweight children <-3 SD; normal children -2 to $1 \mathrm{SD}$; obese $>2$ SD. Caries status of the children was examined by utilizing the deft/DMFT index according to the tenets of the World Health Organization (WHO). Teeth with carious lesion and soft enamel surface were included in the caries category. White spots were not included in the caries lesion category.

The stimulated salivary parameter was measured using GC Saliva Check Kit. Child chews on a paraffin wax for 30 seconds. Children were instructed to sit in an upright body position. The stimulated saliva was collected into the collection cup for 5 minutes to acquire the saliva total volume value, divided by 5 to acquire the value of flow rate saliva in $\mathrm{mL} /$ minute. $\mathrm{pH}$ strips were dipped into the saliva for 10 seconds before taking them out. Saliva $\mathrm{pH}$ strips were compared with $\mathrm{pH}$ indicator paper on the GC Saliva Check Kit. The buffer capacity was measured by dripping saliva into the buffer capacity indicator paper and waited for 2 minutes until the indicator colour changes. All results were written into the examination sheet.

Data was analysed by using the Mann-Whitney test, the ANOVA test, and the Kruskal Wallis test. Statistics analysis used was SPSS version 21.

\section{RESULTS}

According to the characteristics of the 6 to 9 years old of age $(n=17)$, there are 8 boys and 9 girls. For 1012 years old of age $(n=47)$, there are 26 boys and 21 girls (Table 1).

The result of the statistical analysis using the MannWhitney test shows that there was no significant difference between age, BMI, deft and DMFT towards male and female depending on the age. The result of statistical analysis using the ANOVA test shows that there was a significant difference between volume $(\mathrm{p}=0.001)$, flow rate $(\mathrm{p}=0.001)$ and saliva $\mathrm{pH}(\mathrm{p}=0.001)$ for underweight, normal and obese children. The statistical analysis using the Kruskal Wallis test showed no significant difference between buffer capacity, deft, and DMFT for underweight, normal, and obese children.

Table 1. Comparison of variable frequency for children aged 6-9 years old and 10-12 years old

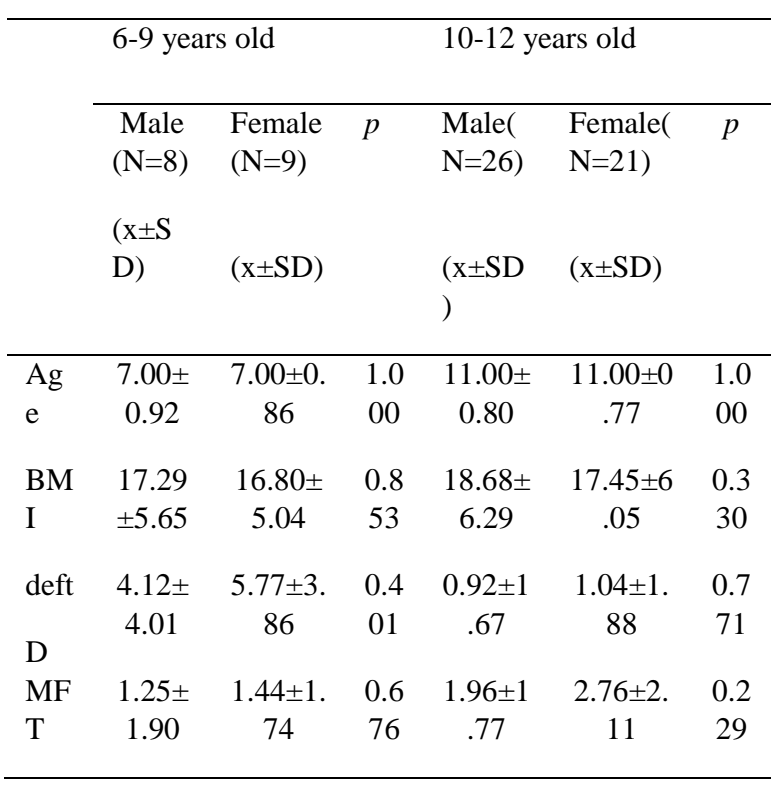

Table 2. Comparison of variable frequency between underweight, normal, obese children

\begin{tabular}{|c|c|c|c|c|}
\hline & $\begin{array}{l}\text { Underweigh } \\
\mathrm{t}(\mathrm{N}=25) \\
(\mathrm{x} \pm \mathrm{SD})\end{array}$ & $\begin{array}{l}\text { Normal } \\
(\mathrm{N}=25) \\
(\mathrm{x} \pm \mathrm{SD})\end{array}$ & $\begin{array}{r}\text { Obese } \\
(\mathrm{N}=25) \\
(\mathrm{x} \pm \mathrm{SD})\end{array}$ & $p$ \\
\hline Age & $10.32 \pm 1.51$ & $\begin{array}{c}9.40 \pm 1.8 \\
4\end{array}$ & $\begin{array}{c}9.68 \pm 2.0 \\
3\end{array}$ & $\begin{array}{l}0.1 \\
99\end{array}$ \\
\hline BMI & $12.43 \pm 0.42$ & $\begin{array}{c}16.33 \pm 1 \\
59\end{array}$ & $\begin{array}{c}25.64 \pm 3 \\
36\end{array}$ & $\begin{array}{l}0.0 \\
00^{*}\end{array}$ \\
\hline Volume & $2.66 \pm 1.63$ & $\begin{array}{c}4.84 \pm 2.2 \\
8\end{array}$ & $\begin{array}{c}1.36 \pm 0.2 \\
7\end{array}$ & $\begin{array}{l}0.0 \\
01 *\end{array}$ \\
\hline $\begin{array}{l}\text { Flow } \\
\text { Rate }\end{array}$ & $0.53 \pm 0.22$ & $\begin{array}{c}0.96 \pm 0.4 \\
5\end{array}$ & $\begin{array}{c}0.32 \pm 0.0 \\
6\end{array}$ & $\begin{array}{l}0.0 \\
01 *\end{array}$ \\
\hline $\mathrm{pH}$ & $7.59 \pm 0.22$ & $\begin{array}{c}7.62 \pm 0.2 \\
0\end{array}$ & $\begin{array}{c}7.31 \pm 0.3 \\
3\end{array}$ & $\begin{array}{l}0.0 \\
01 *\end{array}$ \\
\hline $\begin{array}{l}\text { Buffer } \\
\text { Capacity }\end{array}$ & $8.48 \pm 3.79$ & $\begin{array}{c}9.44 \pm 2.8 \\
0\end{array}$ & $\begin{array}{c}7.60 \pm 3.1 \\
6\end{array}$ & $\begin{array}{l}0.1 \\
49\end{array}$ \\
\hline Deft & $2.68 \pm 3.61$ & $\begin{array}{c}1.16 \pm 1.5 \\
9\end{array}$ & $\begin{array}{c}2.04 \pm 2.9 \\
2\end{array}$ & $\begin{array}{l}0.5 \\
54\end{array}$ \\
\hline DMFT & $2.44 \pm 2.08$ & $\begin{array}{c}1.16 \pm 1.1 \\
7\end{array}$ & $\begin{array}{c}2.12 \pm 2.2 \\
9\end{array}$ & $\begin{array}{l}0.1 \\
02\end{array}$ \\
\hline
\end{tabular}

$* \mathrm{p}<0.05$ 


\section{DISCUSSION}

This study was conducted on primary school students in Medan city to analyse the differences between nutritional status, salivary parameters, and caries status. The mean age of underweight children was $10.32 \pm 1.51$, as for normal children were $9.40 \pm 1.84$, and obese children were 9.68 \pm 2.03 . The mean BMI value of the underweight children was $12.43 \pm 0.42$, as for normal children were $16.33 \pm 1.59$, and obese children were $25.64 \pm 3.36$ (Table 2).

The current study presented the average salivary volume and flow rate of underweight and obese children to be lower compared to the normal BMI group (Table 2). The stimulated salivary flow rate was considered as hypo salivation if the measured flow rate was below $0.7 \mathrm{~mL} /$ minute. Based on our findings, both underweight and obese children were experiencing hypo salivation. Doaa et al. asserted that hypo function of the salivary gland is a common finding in underweight children and often results in diminished saliva flow rate [2]. Plesis hypothesized that there may be a correlation between malnutrition and parotid swelling. Their research implied that the swelling of the parotid gland is primarily caused by the acinus enlargement. In another case report, enlarged acini cells did not display secretory granules, thus this may be the causal factor to the aberration in saliva secretion [8]. Ain's affirmed that due to over-accumulation of fat tissue (adipose) in the salivary glands of obese children, the salivary ducts and acinus may have enlarged. The swelling of the salivary glands leads to decreased salivary flow rate. Other than a high adipose accumulation, obese children seemed to have a high level of systemic macrophages as well. Macrophages function to elicit the production of inflammatory cells which would facilitate the inflammation process. Abnormally high levels of macrophages can continuously stimulate active inflammatory processes in obese children which would disrupt the salivary gland and consequently lead to decreased saliva flow rate [9].

The mean $\mathrm{pH}$ of underweight and obese children was considerably lower compared to the normal BMI group (Table 2). Consistent with our findings, Anamaria asserted that the mean $\mathrm{pH}$ of normal children was higher compared to the mean $\mathrm{pH}$ of the underweight and obese children [11]. In the present investigation, the mean buffer capacity of underweight and obese children was undoubtedly lower compared to children with normal BMI (Table 2). This condition may be prompted by the low salivary flow rate. With decreased saliva flow, the bicarbonate concentration subsequently plummets. Bicarbonate is one of the fundamental components that provide the buffer effect in saliva; hence when the bicarbonate ion concentration reduces, this will lead to lower buffer capacity [12]. According to Johansson et al., other than lower bicarbonate ion concentration, other factors may impact on the buffer capacity such as genetics and dietary habit [13]. Therefore, regulation of optimum buffer capacity would, in turn, regulate the saliva $\mathrm{pH}$ in children [11].

Dental caries is a multifactorial process that encompasses the host, microorganisms, substrate, and time. Our research had displayed a higher mean deft/DMFT in underweight and obese children compared to the average deft/DMFT in normal children (Table 2). According to the deft/DMFT index established by the World Health Organization (WHO), the mean deft/DMFT in this study was classified in the low category. Anamaria claimed that the mean deft/DMFT of underweight and obese children was higher compared to normal children [11]. The high incidence of caries in underweight and obese children was instigated due to severe hypo salivation experienced by the children. As previously mentioned, hypo salivation in children could disrupt the salivary secretion, thus cumbering the role of the saliva as a selfcleaning agent [10,11]. According to Jayaraj and Ganesan, the saliva flow rate is suspected to be the predominant factor in promoting caries [14]. The high frequency of a fat-rich-diet in obese children is an important predisposing risk factor of dental caries in children and should not be underestimated [9].

\section{CONCLUSION}

The present study had demonstrated that there is a significant relationship between BMI and saliva volume, flow rate, and $\mathrm{pH}$. Underweight and obese children exhibited a lower mean saliva volume, flow rate, $\mathrm{pH}$ and buffer capacity compared to the children with normal BMI. This study also predicted that BMI has an impact on the caries status of primary school children as the underweight and obese groups are more vulnerable to dental caries.

\section{REFERENCES}

[1] Siregar YH, Ernalia Y, Restuastuti T 2016 Gambaran status gizi pada siswa sekolah dasar di Desa Teluk Kiambang Kecamatan Tempuling Kabupaten Indragiri Hilir. JOM FK. 3 1-13

[2] Hashem DS, Bayoumy SY, Fahmy WA 2016 Effect of childhood malnutrition on salivary flow dan pH. ADJ-for Grils. 3 141-5

[3] WHO Malnutrition quantrition quantifying the health impact at national and local levels. 2005 Geneva 1-4

[4] Aluckal E, Anzil KS, Baby M 2016 Association between body mass index and dental caries among anganwadi children of Belgaum City, 
India. J Contemp Dent Prac. 17 844-8

[5] Uzogara SG 2016 Underweight, the less discussed type of unhealthy weight and its implications review. JFSNR. 3 126-42

[6] Kementrian Kesehatan RI 2010 Standar antropometri penilaian status gizi anak Jakarta. $5-40$

[7] Kasuma N 2015 Fisiologi dan patologi saliva. (Padang: Andalas University Press) p 1-19

[8] Plessis DJ 1956 Parotid enlargement in malnutrition. S A Med J. 30 700-3

[9] Ain T, Sultan S, Gowhar O 2016 Obesity and salivary parameters (flow rate, buffer capacity, and salivary $\mathrm{pH}$ ) in children of Morabad, India Int J Sci. 4 25-9

[10] Almeida PD, Gregio AM, Machado MA 2008 Saliva composition and functions: a comprehensive review. J Contemp Dent Prac. 372-80

[11] Bud A, Bud E, Esian 2017 Interrelation between salivary $\mathrm{pH}$, buffer capacity and dental caries in underweight, normal weight and overweight children. Rev Chim (Bucharest) 68 1353-6.

[12] Pramod JR 2014 Textbook of oral medicine. (New Delhi: Jaypee Brothers Medical Publisher) p. 60-4.

[13] Johansson I, Saellstrom A, Rajan B 1992 Salivary flow and dental caries in Indian children suffering from chronic malnutrition. Caries Res. 26 38-43

[14] Jayaraj D, Ganesan S 2015 Salivary pH and buffering capacity as risk markers for early childhood caries:A clinical study. Int J Clin Pediatr Dent 8 167-71 